\title{
Comparative study of rabbit crossbreeding, between-breed and within-breed relationships between traits of the terminal products
}

\author{
J. OUHAYOUN et B. POUJARDIEU(*) \\ Laboratoive de Recherches sur l'élevage du Lapin, \\ Centre de Recherches de Toulouse, I.N.R.A., 3I320 Castanet-Tolosan (France) \\ (*) Station d'amélioration génétique des animaux, \\ Centre de Recherches de Toulouse, I.N.R.A., 3I320 Castanet-Tolosan (France)
}

A total of 325 hybrid young rabbits of both sexes, born of nulliparous females I.N.R.A. I 067 and of males from seven strains differing in adult weight, weaned at 4 weeks, contemporaneously raised in individual cages, fed ad libitum with the same standard diet and killed at I I weeks, were examined.

The paternal strains were giant-sized (Geant des Flandres : $5,8 \mathrm{~kg}$; Géant du Bouscat : $5,3 \mathrm{~kg}$ ), middle-sized (I.N.R.A. I027, experimentally selected on growth rate : $3,8 \mathrm{~kg} ;$ I.N.R.A. IOT7 control strain raised without selection : $3,7 \mathrm{~kg}$; Rex Havane : $3,5 \mathrm{~kg}$ ) or small-sized (I.N.R.A. I089: $2,8 \mathrm{~kg}$; Nain de Couleur : $1,7 \mathrm{~kg}$ ). The adult mean weight of females I.N.R.A. I067 was $3,6 \mathrm{~kg}$.

At I w weeks, the carcass fatness and the dry matter and lipid contents of muscle tissue were high in the hybrids from small-sized paternal strains and, within-type of crossing, in the heaviest young rabbits. The feed conversion ratio between 4 and I I weeks was lower both in the rabbits of large-sized strains and, within-type of crossing, in the heaviest rabbits at I weeks.

These results indicate that the productive efficiency and the body maturity present different relationships between or within genetic types. In the latter case, it appears that a high maturity at killing and a reduced production cost are compatible objectives.

\section{VI. - HYGIENE; AND PATHOLOGY}

\section{Obtaining and rearing of axenic and gnotoxenic rabbits. The heteroxenic rabbit: first results}

\author{
J. DABARD \\ Centre d'élevage et de sélection des animaux de laboratoive, C.N.R.S., \\ 45045 Orléans Cedex (France)
}

Young rabbits obtained by aseptic hysterectomy were raised in an isolator and fed either with artificial milk derived from cow's milk or with rabbit's milk. The artificial milk was autoclaved for 20 min. at $120^{\circ} \mathrm{C}$ whereas the rabbit's milk was sterilized by irradiation (4 Mrads) after 1yophylization. The young were kept in the axenic state until weaning ( 28 days); thereafter they received either BRomon's's flora of 3 bacteria, or a mixture of strictly anaerobic bacteria from rats or mice, capable of reducing the developpement of the caecum in the rat, or a mixture of 8 bacteria from the hare caecum and allowing the gnotoxenic hare to survive.

Among the 82 young rabbits fed with the artificial milk only 4 were weaned; 5 died from false deglutition and $5 \mathrm{I}$ from allergic-like pneumonia. Among the $7^{2}$ young rabbits fed with rabbit's milk, 52 were weaned; 13 died from false deglutition, ro from an intestinal haemorrhagic syndrome. The growth of the axenic young receiving rabbit's milk was similar to that of the conventional young rabbits.

The axenic young died after weaning and their caecum was hyperdeveloped. The rabbits harboring a mictoflora survived. In the case of the trixenic flora, the hyperdevelopment of the caecum was detrimental to pregnancy. Rat and mouse flora reduced the development of the caecum; in the case of the hare flora including 8 bacteria, a reproductive life was possible. 